\title{
Business Growth
}

\author{
"Business Growth is \\ Never by \\ Mere Chance; \\ It is the Result of \\ Forces
}

Working Together"

-James Cash Penny 



\title{
CASE CHAPTER 3 \\ Steve on a Stevey Journey: On the Course of Business Growth to Tackle Competition in \\ Kazakhstan
}

\author{
Yevgeniya D Kim \\ Bang College of Business, \\ KIMEP University, Almaty, Kazakhstan. \\ ydk@kimep.kz
}

\section{Abstract}

The present case study talks about a consulting company named St. Consulting. The business is owned and managed by Steve Robes, who serves the company as chief operating officer. The company offers consultancy services to local businesses in Kazakhstan. Steve and his seasoned team of consultants provide consulting services to small and medium-sized enterprises on matters including business development, marketing, customer attraction, product development and customization, business operations, and sales performance. The case presents insight on the issue related to business growth and how enterprises such as St. Consulting may ideally tackle the issue. The case contains rich information on a tricky situation faced by the company and how the $\mathrm{COO}$ has been working to address the issue to the best of his capabilities.

\section{Synopsis}

It was early Friday morning when Steve received the daily newspaper, which he loved reading while having his first cup of coffee for the day. As usual, Steve went straight to page 11 of the local 
newspaper, where businesses advertise products and services and got shocked to see advertisements of several consulting businesses. He could sense that he needs to do something before it is too late. Though he had noticed it happening sooner or later due to economic reforms and business acceleration in the region but this time, he was even more surprised as he had seen advertisements of consulting businesses opening in the capital city of Nur-Sultan; the same place where St. Consulting is based.

\section{St. Consulting}

St. Consulting was owned and operated by Steve Robes. The company was established in 1997 in the city of Nur-Sultan and provided consulting services to small and medium enterprises in the country and the nearby region on business development, marketing, product development and customization, human resources, business operations, sales performance, public relations, and project management. The company had a central business unit in Affari and employed specialized people in all the domains they offer services. St. Consulting employed a total of 18 consultants, three project specialists, and two finance and risk assessment advisors. Apart from the consulting team, St. consulting also employed senior manager customer care and three general staff members. The company had served 483 small and medium scale entrepreneurial initiatives and was associated with 11 entities on different matters. Steve and his business had been recorded and reported in popular magazines and newspapers in the country and nearby region and has also won the best business and top business accelerator award in the past. The company held a unique position in the market and has a huge clientele record. In the words of Ms. Shanzar, who worked as senior manager customer care,

"St. Consulting has rich experience in providing consulting services of nearly all kinds. Our consultants are seasoned and well versed in their fields. We hardly miss clients, and this is something we are proud of." 


\section{Steve}

Steve Robes was an experienced consulting professional with decades of experience in the field. He was born in the migrant family and spent most of the early years of his life in Nur-Sultan, the capital of Kazakhstan. Being the eldest kid in the family of Mr. Robes, Steve received much love, care, and support from his family to live his life to the fullest. In his own words, he described,

'I have always remained blessed right from childhood till now. As the first child to my parents, I received much love and affection from the immediate and extended family members. I always remained close to my father, and he was the one who inspired me to do what I would love doing, and so I started consulting business.'

Talking about how and when the idea of starting St. Consulting came to him he said,

'You see, the idea of doing what I love was already infused in me by my father since my childhood, but I didn't know precisely what is that I will be holistically passionate about. But then it was the last semester of my bachelor's in business studies degree where we had to work on a group project to develop a business plan for any company of our choice. Therein, I came up with the idea of writing and submitting a business plan for some kind of service entity. After a series of discussions with the assigned team members (class-mates), we decided to develop a business plan for a consulting company. We worked very hard on the project whereby, there was not much internet access available conveniently. We did the market survey, trend analysis, financial assessment, feasibility report, time plan, and so on. We secured $A+$ grade in our project, and I still have a copy of the project with me. That was the point exactly where I decided to start my own consulting business.'

Mr. Steve seemed very much in love with his business and the idea of consulting services, which was clear from his sparkling eyes and how passionately he recalled the start of his entrepreneurial journey. While responding to challenges, he faced at the beginning he mentioned, 
'Journey of an entrepreneur is not easy. They go through a lot of challenges, and so do I. When you aspire to live your dream, you have to be willing to compromise on the comforts of life. When I decided to start my own consulting business in 1997, I also prepared myself for all the problems and hurdles mentally. Starting from registering the business to recruiting people, contacting businesses for our services, setting up a physical business unit, everything was a firsthand experience, and I didn't have had much of technical support on all these matters. But as they say, when there is a will, there is a way, and so the same happened. During all those initial years of my struggle, my father remained a great source of motivation and encouragement though being a farmer himself, he had little to guide me on the consulting business in specific. Nevertheless, his guidance and encouragement to me on hard work with one direction, honesty to oneself and others, and commitment to the responsibilities is something I benefit from till date.'

\section{Call for Meeting}

Right after going through the newspaper advertisements of the consulting companies opening in the capital and other cities nearby, Steve called Mr. Erasyl, the office manager, to arrange a meeting at 4 PM (end of the business day) and to be attended by all except the office support staff members.

\section{Start of the Meeting}

Steve came well in time for the meeting and went straight to the meeting room. Seeing this, everyone started rushing to the meeting room. Everyone could notice a sense of restlessness and urgency on his face. It was not even 4:00, and he called Erasyl to get everyone if they are done here for an important discussion. He asked the office assistant to make copies of the newspaper advertisement that he had brought along by 3:58 PM every concerned official required was in the meeting room. Steve asked the assistant to float the idea what she was asked to photocopy to everyone and said, 
'Good evening everyone. I know it is an impromptu meeting, and some of you might be too busy finalizing their work before the weekend, but this is something important for all of us. Now you have been given photocopies of some newspaper advertisements what is it and why I have brought them to you?'

When he asked this, people started saying these are advertisements of other consulting companies. Someone said, do you want us to compare these ads with our company advertisements? And then Alinur, who is one of the consultants in the company, said, sir, I believe you are trying to alarm us for potential business challenges in the near future. When Steve heard this, he said YES!!!

'This is what I wanted you to highlight. Not only us, but everyone can see that our economy is booming, and Kazakhstan is gearing for an era of massive economic revamp, which would bring more competition in the market, and this has started happening already ladies and gentlemen' said Steve.

'Now since we are a well-established business in the consultancy sector, naturally entrepreneurs are reaching out to us, but don't forget that other companies must be trying very hard out there to grab a share from the market.'

'So you mean we need to kick start our strategies from now to tackle them,' Said Alinur to which Steve said, 'absolutely; there is no other option.'

'Now the big question is how to go about doing this? I would like to hear from you people', said Steve.

The crowd started brainstorming and coming up with ideas. Sadly, none of the ideas fascinated Steve, as shown below:

\begin{tabular}{|c|ll|l|}
\hline No & \multicolumn{2}{|c|}{ Ideas/Potential Options } & \multicolumn{1}{c|}{ Plausible Concerns } \\
\hline 1 & $\begin{array}{l}\text { Reducing } \\
\text { charges to attract new }\end{array}$ & $\begin{array}{l}\text { Reducing our services charges may } \\
\text { rather affect our reputation with }\end{array}$ \\
\hline
\end{tabular}




\begin{tabular}{|c|c|c|}
\hline & $\begin{array}{l}\text { clients and retain the } \\
\text { existing }\end{array}$ & $\begin{array}{l}\text { clients thinking we charged them } \\
\text { more in the past }\end{array}$ \\
\hline 2 & $\begin{array}{l}\text { Offering discounts on } \\
\text { services }\end{array}$ & $\begin{array}{l}\text { Discounts may work in the short run } \\
\text { but not in the long run }\end{array}$ \\
\hline 3 & $\begin{array}{l}\text { Improved } \\
\text { services }\end{array}$ & $\begin{array}{l}\text { The company already offers several } \\
\text { domestic and commercial packages } \\
\text { for the new and existing clients }\end{array}$ \\
\hline 4 & $\begin{array}{l}\text { Collaborating with the } \\
\text { new or existing } \\
\text { competitors }\end{array}$ & $\begin{array}{l}\text { St. Consultancy will have fewer } \\
\text { benefits to reap from this, } \\
\text { particularly if we hit for } \\
\text { collaboration with new entrants. }\end{array}$ \\
\hline 5 & $\begin{array}{l}\text { Loyalty based } \\
\text { membership scheme }\end{array}$ & $\begin{array}{l}\text { It would take time to reap benefits } \\
\text { and also needs a responsive } \\
\text { technological advancement in place, } \\
\text { which would also take some time } \\
\text { and money. }\end{array}$ \\
\hline 6 & $\begin{array}{l}\text { Diversify into other } \\
\text { consultancy domains such } \\
\text { as mortgages for business, } \\
\text { FDIs management foreign } \\
\text { direct investment } \\
\text { management) }\end{array}$ & $\begin{array}{l}\text { Required time to develop skills } \\
\text { and/or hire individuals to assist. } \\
\text { Possibility to face huge competition } \\
\text { from the existing service providers. }\end{array}$ \\
\hline 7 & $\begin{array}{l}\text { Look for the possibility for } \\
\text { opening offices in the } \\
\text { other parts of the country }\end{array}$ & $\begin{array}{l}\text { Already working with three sub- } \\
\text { offices in three different cities. } \\
\text { Extending the business requires } \\
\text { having reports/evidence of } \\
\text { accelerated business activity in the } \\
\text { city(ies) }\end{array}$ \\
\hline 8 & $\begin{array}{l}\text { Looking for options in } \\
\text { extending to other } \\
\text { countries in the region of } \\
\text { potential (e.g., Azerbaijan) }\end{array}$ & $\begin{array}{l}\text { Requires comprehensive market } \\
\text { study minimum 6-month time } \\
\text { needed. }\end{array}$ \\
\hline
\end{tabular}


The ideas seemed to be interesting and very diverse, but Steve seemed clueless to say anything about selecting any of those with confidence. At 5.25 PM, Steve said,

"I guess we need to call it a day now, but I would like to urge you all to give this issue a thought over the weekend and let us meet again the same time next Thursday. Please go through market reports and do some research on current practices of competitors in the market while keeping in view the options we discussed today. Please do look for what other companies are strategizing for. Use your contacts over the next week to see if we can get some better insights on the issue. We might come up with some other options, and I am sure we will. It is a matter of company existence and our jobs in the long run, and we have to work for it to avoid any unintended consequences strategically."

So, Steve and his team have big decisions to make in the near future. The company holds a strong reputation and existence in the market, but keeping in view the market growth and increased competition, St. Consulting requires to take adequate measures before its too late. The company has to be very careful in what they choose to strengthen themselves in the market for better prospects, but that decision has to be made wisely with precision to refrain from any waste of time, resources, and efforts.

\section{Discussion Questions}

Q1. What is your opinion about Steve as a Business Consultant? Q2. How do you see the St. Consulting as a Business?

Q3. Keeping the market reputation and the big number of satisfied clients, do you think Steve is correct in his concerns, or he is just a little too concerned?

Q4. Being in place of Steve, what option will you opt for the company for handling competition and business growth, and why?

Q5. Which option you think would be the second-best choice for St. Consulting, and why? 
Q6. Imagine St. Consulting hiring you as an external consultant to advise them apart from the options discussed above. What would be your advice and option(s) to them on the matter?

\section{Suggested Readings}

Anderson, M. (2016). Strategy: "How to Crush The Competition - Tactics For Business Growth \& Development " $2^{\text {nd }}$ Edition. Create Space Independent Publishing. Scotts Valley California USA

Kozhanova, N. (2019). Kazakhstan experiences industrial growth, takes efforts to continue growth. Available at: https://astanatimes.com/2019/04/kazakhstan-experiences-industrial-growthtakes-efforts-to-continue-growth/.

Stronski, O. (2019). Cooperation and Competition: Russia and China in Central Asia, the Russian far east and the arctic. Available at: https://carnegieendowment.org/2018/02/28/cooperation-and-competitionrussia-and-china-in-central-asia-russian-far-east-and-arctic-pub-75673.

Umrani, W. A., Kura, K. M., \& Ahmed, U. (2018). Corporate entrepreneurship and business performance: The moderating role of organizational culture in selected banks in Pakistan. PSU Research Review, 2(1), 59-80.

Umrani, W.A., Doudpota, A.K., \& Ahmed, U. (2016). ICON Stores: Managing a new business venture. Emerald Emerging Markets Case Studies, 6(1), 1-20.

\section{Exhibit 1: Country Information}

\begin{tabular}{|l|l|}
\hline Country Name & Kazakhstan \\
\hline Capital & Nur-Sultan \\
\hline GDP & $\$ 164.3$ million \\
\hline GDP Growth & $4.1 \%(2018)$ \\
\hline Population & 18 million $(2017$ est) \\
\hline Area & 2.7 million square meters \\
\hline Major Languages & Kazakh, Russian \\
\hline Life expectancy & 68 years (men) 77 years (women) \\
\hline
\end{tabular}




\begin{tabular}{|l|ll|}
\hline $\begin{array}{l}\text { Major National Projects in } \\
\text { Progress (related to business } \\
\text { growth) }\end{array}$ & $\begin{array}{l}13 \text { in Almaty, Nur-Sultan, East } \\
\text { Kazakhstan, Shymkent and } \\
\text { Pavlodar. }\end{array}$ \\
\hline Largest Business City & Almaty & \\
\hline Ease of Doing business Rank & $28^{\text {th }}$ out of 190 & \\
\hline Global Competitive Rank & $59^{\text {th }}$ out of 190 & \\
\hline $\begin{array}{l}\text { Major International Partnership } \\
\text { with other countries }\end{array}$ & $\begin{array}{l}\text { China Russia, USA and } \\
\text { Neighboring region }\end{array}$ & \\
\hline
\end{tabular}

Sources: World Bank: Overview Kazakhstan 2019; US Government: Market Overview Kazakhstan 2019

\section{References}

US Government. (2019). Market Overview Kazakhstan 2019 Retrieved from: https://www.export.gov/article?id=Kazakhstan-Market-Overview. [Accessed 19 June 2019]

World Bank. (2019). Overview Kazakhstan. Retrieved from: https://www.worldbank.org/en/country/kazakhstan/overview. [Accessed 15 July 2019]

(C) 2020 by the author(s). Published by Annals of Emerging Technologies in Computing (AETiC), under the terms and conditions of the Creative Commons Attribution (CC BY) license which can be accessed at http://creativecommons.org/licenses/by/4.0. 